\title{
Determining the Contribution of Abdul Karim Searching the History of Bara-Bhuiyans against Mughal Empire in Bengal
}

\author{
MD. Cholem Ullah
}

Assistant Professor in Islamic History and Culture, Centre for University Requirement Courses (CENURC), International Islamic University Chittagong (IIUC), Bangladesh

DOI: $\underline{10.36348 / \text { sjhss.2021.v06i02.006 }}$ | Received: 08.02.2021 | Accepted: $20.02 .2021 \mid$ Published: 26.02 .2021

*Corresponding author: MD. Cholem Ullah

\section{Abstract}

The age of Bara-Bhyuian (1576-1612) or reign of the twelve landlords of the East region of Bengal is a famous chapter in Bangladesh's history. According to the historical investigation of Abdul Karim, the article aims at exploring about forming of a series of military resistance and struggle of Bara-Bhyuian against Mughal imperial power those newly emerged from northern India and subsequently captured their jurisdiction all over the Indian subcontinent along with Bengal territory. Historically it was a fact that the Twelve Zamindars waged an armed struggle for many years to keep their homeland free from colonial imperialist power. Unfortunately, the glorious chapter of this Bara-Bhuiyans was not highlighted properly by the historians for a long time. Even their identity and subjugated areas were not explored and recognized since many centuries rather than the time been obscured and uncovered in Bengal by either native or alien scholars. On the contrary, historians didn't concentrate the time accordingly what the period deserves from the scholars. So, Abdul Karim was the pioneer for the first time among historians who took the chapter as one of the vital focal place of Bengal history during Mughal expansion. Thus, the paper seeks to prove that what contribution marked by Abdul Karim about Bara-Bhuiyans in the sacrifices and struggles they waged to liberate their independent motherland that have inspired every freedom struggle so far.

Keywords: Abdul Karim, Bara-Bhuiyans, Bengal, Mughal, historians, struggle.

Copyright ( $\odot 2021$ The Author(s): This is an open-access article distributed under the terms of the Creative Commons Attribution 4.0 International License (CC BY-NC 4.0) which permits unrestricted use, distribution, and reproduction in any medium for non-commercial use provided the original author and source are credited.

\section{INTRODUCTION}

Bangladesh emerged as an independent country in 1971 since the nine-month liberation war against Pakistan and occupied a glorious place in the world. But the country has a long history of striving with the spirit of resistance against many foreign aggressions for achieving independence. One such chapter of the freedom struggle was the fearless and long struggle of the Bara-Bhuiyan $\left[{ }^{1}\right]$. In the Bhati $\left[{ }^{2}\right]$ region of Bengal against the Mughal $\left[{ }^{3}\right]$ aggression. Of course, many independent and semi-independent zamindars $\left[{ }^{4}\right]$ (Landlords) took their arms and stranded individually and untidily against Mughal aggression and its colonial expansion in the last quarter of the $16^{\text {th }}$ century and the first 12 years of $17^{\text {th }}$ century for a long time (1576-1612) in Bengal. But the history of these three decades (1576-1612) is that the zamindars of Bengal have a history of long resistance and war against the Mughal domination to keep their independence and sovereignty intact. A prominent historian of Bangladesh Abdul Karim is the proponent of this historical research and among many known and unknown historians who record Bar-Bhuiyan and their history properly. He established the Bar-Bhuiyan of Bengal in its proper place and dispelled various misconceptions about BaraBhuiyan by the local and foreign historians of past and present.

Studying various resources and references of the history of Bara-Bhuiyan neutrally, Abdul Karim explored much new magnificent information related to Bara-Bhuiyan and added various fresh chapters in his research that was able to generate a complete response indeed in the research community. It was not really that Mughal dominion was started over Bengal with the fall of Bengal sultan Daud khan Karrani $\left[^{5}\right]$ in 1576 . So the period of 36 years in Bengal's history from 1576-1612 not be considered as Bengal's Mughal period. During this time, numerous parts of Bengal remained under the control of military officers, bhuiyans and zamindars. There was no central government so this time could be called the bhuiyans' time. Bara-Bhuiyans became very 
famous amongst the bhuiyans, fighting bravely during Akbar and Jahangir's first part.

Abdul Karim gave the proper status of BaraBhuiyan to all the patriotic and independent Bhuiyanas or zamindars of Bengal, who resisted the foreign Mughal domination. Although some insignificant zamindars surrendered in the first blow of the Mughal invasion, the Bara-Bhuiyan of Bhati of Bengal had fought relentlessly for three decades with patriotism and courage. Comparatively, Bara-Bhuiyan was inferior in considering all military equipment and strength to Mughal power. Still, holding morale, courage and patriotism, they embarked on a hard strive against that foreign occupier. They fought up to their death, but they had never submitted loyalty to colonial dominion. Besides, some Bhuiyans were forced to surrender to Mughal - but when they used to get any chance for achieving freedom, they would arise rivalry and would rebel with arms again and again. Thus, from 1576-1612 Bengal was controlled by several Bhuiyans. Among them, the Bara-Bhuiyans vitally also played a more prominent role in resisting Mughal; even during the present time, the Bangalees feel proud of their courageous battle.

This article followed the secondary type source is approaching its methodology. This paper is qualitative oriented research based on desk type works.

\section{Appreciation of Contemporary Historical Works and Abdul Karim}

After the reign of Bara-Bhuiyans, their history was insolence and completely lost for more than two centuries. Even in the book Riyaz-us-Salatin $\left[{ }^{6}\right]$ what is entitled the first complete history of Bengal, even in the first modern history regarding Bengal 'History of Bengal' $\left[{ }^{7}\right]$ written by Captain Charles Stewart was not found anything about Bara-Bhuiyans. But the history of that time came to the governmental researchers' attention on the eve of taking the permanent settlement policy as the land revenue reform by the British East India Company's government. C. W. B. Rouse presented the real information of Bara-Bhuiyans accurately in his book "Dissertation Concerning the Landed Property of Bengal" $\left[{ }^{8}\right]$. He brought out the fact that at the time when the Afghans made their way out to make space for the Mughals, Bengal did not belong to Mughals or any single ruler, but was occupied among some practically independent military commanders named Bhuiyans - some of them were Hindus, but most were Muslims. British civil surgeon of Dhaka James Wise devoted himself to writing the history and archeology of Bengal. He also got a source of dissemination of interest from the works of C. W. B. Rouse. He was able to discuss five Bhuiyans from his collected references and resources, and he published the research on Bara-Bhuiyans entitled "On the BaraBhuiyans of Eastern Bengal" in $1874 \mathrm{AD}\left[{ }^{9}\right]$. In the article by James Wise, the Five Bhuiyans are:
1. Isa Khan Masnad-I-Ala of Khizirpur

2. Fazal Ghazi of Bhawal

3. Lakshmana Manikya of Bhulua

4. Chand Rai and Kedar Rai of Bikrampur

5. Kandarpa Narayan of Chandradvip.

In the same decade, $\mathrm{H}$. Blochman tried to shed light on one or other Bhuiyans in his "Contributions" $\left[{ }^{10}\right]$ and in his translation of the Ain-i-Akbari $\left[{ }^{11}\right]$ Westland in his "Jessore," and Beveridge in his book "Bakarganj "[ $\left.{ }^{12}\right]$. While their studies did not explicitly concern the Bhuiyans or the Bara-Bhuiyans. Earlier in 1904, Beveridge addressed Bara-Bhuiyans' chief Isa Khan in an essay in a journal. Through then, he had almost completed the Akbarnama's English translation (Akbar's autobiography). He thus succeeded in using the references on Isa Khan in the Akbarnama in that article, but he failed to place Isa Khan in a proper historical context. In fact, as an imperial historian, Beveridge was so loyal to the British so that he addressed the issues from the imperial Mughal perspective and did not pay attention to the Bara-Bhuiyans and particularly Isa Khan's struggle for independence N. K. Bhattasali commented that however, it would seem that Beveridge, too, has failed to understand the greatness of Isa Khan's life-long fight for independence and has not devoted to it the thoughtful consideration it deserves. Since dealing in some length with the subject, he very marginally and unexpectedly refers to some pages of the Akbarnama in which more descriptions of the doings of Isa Khan are to be found and then go off to address some small and unimportant matters [ $\left.{ }^{13}\right]$ However, it would appear that he, too, failed to appreciate the greatness of Isa Khan's life-long struggle for independence, and he was not a devotee to it the regardful interest it deserves. After dealing with the subject at some length, he somewhat lightly and abruptly refers to some pages of the Akbarnama in which further details of Isa Khan's doings are to be found and then goes off to discuss some minor and unimportant issues.

The next contributor H. E. Stapleton who discovered some canons $\left[{ }^{14}\right]$. Diwanbagh, the residence of Isa Khan's successors and their family members, is located in modern Narayanganj district near Dhaka. He wrote an article "Note on seven sixteenth-century canons recently discovered in the Dacca District," published in the Journal of ASB in 1909. The canons presented significant light on the Bara-Bhuiyans, and especially one that inscribes Isa Khan's name is very helpful in setting up the chronology in Isa Khan's career. Yet Stapleton could not adequately decode the Bengali alphabet, and the article doesn't have any more detail from the historical post. In 1913, Rev. H. Hosten advertised the subject once again in an article on "The Twelve Bhuiyans or Landlords of Bengal", published in the Journal of the Asiatic Society Bengal in 1913. Utilizing the contemporary writings of Portuguese references, he tried to describe the places Salimabad, 
Katrab, Chandecan named by the Mughal government and sources. He also tried to determine who the Twelve Bhuiyans are and why their number would be set. As the first writer, he pointed out Chandecan's (Chandecan is the previous name of modern Jeaasore district) king was Raja Pratapaditya, and Mughal commanders occupied Jessore on March 1916. After Hosten, J. A. Campos took an attempt to find out about BaraBhuiyans and their areas in his book "History of the Portuguese in Bengal" $\left[{ }^{15}\right]$. But any new information about Bara-Bhuiyans was not seen in the book.

But the unique and very detailed contemporary historical work was the Persian manuscript Baharistani-Gaibi by Mirza Nathan; he was a military officer under subahdar Islam Khan of Mughal during series of military campaigns and operations were preceded against Bara-Bhuiyans in the Bhati of East Bengal.

Numerous articles and books on BaraBhuiyans were published in Bengal. At first, criticizing and supplementing the articles of British James Wise on Bara-Bhuiyans, a series of articles of Kailash Candra Sinha were published Bharati, a Bengali Journal [ ${ }^{16}$ ] After that, Swarup Chandra Roy pointed out some good information about Isa Khan and his territory in the book "Suvarnagramer Itihas" published in 1296 B.S. $\left[{ }^{17}\right]$ Nov. 1890. The next publication was "Pratapaditya." of Satya Charan Shastri in1308 B.S. That book contains traditions and imaginary tales, and "Mayaman-Sinher Itihash" (History of Mymensingh) of Kedarnath Majumdar in 1312 B.S. (1905 A.D.) where some materials on Isa Khan were found newly. But the book holds little historical value as well. In 1802 famous biographical work and regarded as the first Bengali prose "Pratapaditya Charit" of Ram Ram Basu published from Sri Rampur press; this book provides the exact knowledge that the subahdar Islam Khan had defeated Pratapaditya. Even though he has provided some very useful details, his account of Pratapaditya's career is mostly fanciful.

In 1307 B.S. to 1310 B.S., Anandanath Ray published several articles in the two Bengali Magazines Nirmalya and Navyabharat, and all of the articles were finally published into a book in 1318 B.S. Some new knowledge was found in the book. Still, this book lacks order, and historical criticism is deficient. Then those notable writers devoted themselves to the publication of Bara-Bhuiyans they are Upendra Chandra Guha $\left[{ }^{18}\right]$ Satish Chandra Mitra $\left[{ }^{19}\right]$ Sir Jadunath Sarkar, N. K. Bhattasali, M. A. Rahim $\left[{ }^{20}\right]$ can be mentioned.

Sir Jadunath Sarkar presented six articles on the Bhuiyans published on Bengalee Magazine Prabashi (from 1326 B. S. to 1329 B.S.) based on Bahar-i-stan and another unpublished Persian text, are of exceptional quality and provide us for the first time with a contemporary and very detailed account of the wars of Islam Khan with the Bhuiyans, who had managed to preserve their independence for a third of a century during the reign of Akbar and even a part of Jahangir. Yet in some instances, he has failed to correct the chronology and understand the Bara-Bhuiyans' struggle for freedom. He did not identify the Bara-Bhuiyans, either. Furthermore, Sir Jadunath Sarkar brought out on the subject in chapter XII of the book "History of Bengal, Vol. II)" published from the University of Dhaka in 1948; he was also the editor of the volume. He had taken a dismissive approach to the bhuiyans' struggle and doubted their patriotism. Sir Jadunath himself named the "upstarts" and "captains of plundering bands" of the Bara-Bhuiyans and Chiefs.

A collection of papers written by N. K. Bhattasali entitled "Bengal Chiefs' struggle for Independence in the Reigns of Akbar and Jahangir" in the Journal "Bengal: Past and Present" (vol. XXXVXXXVI) in 1928. He first evaluates the previous writings on the subject and then analyses the writings on the Bara-Bhuiyans, the historical process of their rise, and the significance of the term Bara-Bhuiyans. At first, he reviews all previous references on the subject and then examines the Bara-Bhuiyans writings, their emerging on the scale of the historical process, and then the sense of the word Bara-Bhuiyans. In his writings, the collapse of the Karrani Dynasty $\left[{ }^{21}\right]$ the rise of Isa Khan, his whole career, and the extension of his territories with resistance against the Mughals were narrated. Yet a review of his papers gives the thought that he did not complete his study; his research came to an abrupt end for some reason. Afterward, he wrote about Mughals of Dhaka, but he didn't focus on the study on all other Bhuiyans except Isa Khan. While his research is comprehensive, it is limited in scope; there is no complete history of the Bara-Bhuiyans.

The book "History of Bengal, vol. II" edited by Sir Jadunath Sarkar, and undoubtedly the work is much more significant contribution, and superior to either the book Riyaz-us-Salatin or History of Bengal by Stewart. But in the book, Bhuiyans and BaraBhuiyans haven't received sufficient or appropriate attention yet. Moreover, relevant chapters have been written in the context of the Mughal empire and its expansion in Bengal, so the history of Bara-Bhuiyans and the valiant opposition of them have not been given due importance. Despite the hard struggle of the BaraBhuiyans against Mughal aggression in Bengal, they were questioned with patriotism and refuted the valiant position and dignity they deserved by the scholars of the book. None was able to give comprehensive knowledge on the subject after N. K. Bharrasali. Bhattasali's scholarly studies have some limitations, but his works have become models for later scholars. Even Abdul Karim himself acknowledged the works as he has drawn heavily from it as his pattern.

Abdul Karim devoted more room to defining the Bara-Bhuiyans and to determine their success or 
failure. He was the only scholar in Bengal who succeeded in making magnificent and complete history of the Bara-Bhuiyans with comparative analysis of their rising, number and identity, long time heroic resistance against Mughals, dignity, patriotism, military policy, defeating and surrender to Islam Khan, etc. Yet, no other historian has succeeded in studies on the subject till now like him. He discovered a good number of findings on the Bara-Bhuiyans in his book "History of Bengal, vol.1, Mughal Period" published by Institute of Bangladesh Studies of Rajshahi University in 1992, and more than seven chapters of the book out of thirteen with introduction lived in very detail studies of BaraBhuiyans. Apart from this masterpiece, another noteworthy contribution of Abdul Karim to the subject is Banglar Itihas Mogle Amal (History of Bengal Mughal Period) in Bangle and published in 1992 from Bangla Academy. He pointed out also more than seven chapters details of Bara-Bhuians in the book; though the subject matters and detailed discussion are almost the same, amazingly many new dimensions are embodied in Bangla volume regarded references and its narrative style as well.

Abdul Karim analyzed the contemporary inscriptions and coins of the time have been discovered from different parts of Bengal from 1575 to 1612, but the name of Akbar or Jahangir appears in none of these inscriptions or coins, while the names of the ruling kings have usually been engraved in the inscriptions. On the contrary, it was found that Masum Khan Kabuli, Akbar's rebel military captain, declared him independent in Pabna's Chatmohar inscription, and took the title of Sultan-ul-Azam Abul Fath Muhammad Masum. The names of Mughal emperors were not inscribed because the Mughal rule had not been established and there was no other central government in Bengal at the time. And the greater part of Bengal was governed by Bhuiyans during the time. His studies also pointed out that it is difficult to classify the time as the Mughal era. This is the interregnum era, interfering in the transition from Afghan to Mughal rule.

Abdul Karim also remarked that in this period, the absence of Mughal coins issued from any of the Bengal mints during this period gives further support to this view. In the 12th year of the reign of Jahangir, the earliest coin bearing the name of Jahangirnagar (Dhaka) mint was an issue. These, naturally, were issued after Islam Khan subjugated Bengal. The Akbar style Bangla coins, although issued from Bengal, do not bear any mint's name. These coins were issued in the king's 39th year (1593) and continued as far as 1602. They were square bearing coins on the obverse, the Kalima, and the Persian reverse couplet. By 1593, minting activity had begun, but no particular place in Bengal could be identified as a mint town, and the coins produced were designated with the general name of Bengal coins. The couplet of the 'Bangla' coins also hints his series was the first to be graced in Akbarnama in Bengal.

\section{Rise of Bara-Bhuiyans: their names and governed territory}

The Bara-Bhuiyans emerged in the unstable and turmoil political environment of Bengal that appeared immediately after the fall of the Independent Sultanate and sustained for a long time particularly in the Bhati region of East Bengal at that time. Politically, the Independent Sultanate of Bengal glorified its peaceful period of two hundred years (1338 A. D. to 1538 A. D.) in the Bengal history. But Sher Shah $\left[{ }^{22}\right]$ captured Bengal in April in 1538 defeating Ghiyas-udDin Mahmud Shah[ ${ }^{23}$ ] and included Bengal the province of Delhi. However, Mughal emperor Humayun took a step against Sher Khan and subjugated Bengal in July of the same year, and stayed six months in Bengal. And in the next two years (1938-1940), Sher Khan not only reoccupied Bengal in 1939 but also ascended to the throne of Delhi in 1940 by defeating Humayun in some inevitable battles with wonderful war strategy. So, he founded the Suri Dynasty (1539-1564 and Bengal became a dependency of the Delhi Empire under Suri. But in 1564, the last Suri ruler Ghiyas-udDin-III was killed by Taj Khan Karrani, who employed as one of the chief officers under Sher Shah, and the founder sultan (1564-1665) of the Karrani Dynasty (1564-1576) in Bengal.

Thus, these mentioning political transactions prevailed in Bengal as a chaotic period that resulted in socio-political instability, political unrest, and chaos the Bara-Bhuiyans of the Eastern Bengal ascended to power. Abdul Karim stated Bara-Bhuiyans were the heirs to the independent sultanate which was two hundred years old in Bengal. After inspection and examination of the discovered coins of the time, he decided without confusion that Sher Shah or his successor Islam Shah was not able to establish authority in eastern Bengal fully. Hence he remarked for that reason that following the fall of the independent sultanate and predominantly with Sher Shah's decentralization of administration, the chaotic state and disruptive forces prevailed particularly in Eastern Bengal, in the Bhati region.

None of Sher Shah or Humayun could establish authority in Bengal as a whole during the unrest, since two years of Sher Shah's conflict of power. The outlying area would have been outside of their effective jurisdiction except for the capital city of Gaur. Bengalees had tasted independence for a long time and now they didn't remain only idle viewers of the AfghanMughal conflict and its result. That is why Delhi used to find Bengalees the Balghakians (rebels or people prone to rebellion) and Bengal the Balghakpur (rebellious country) $\left[{ }^{24}\right]$. Besides, Bengal is riverine deltaic land; the particularly eastern side of Bengal is full of streams, revivers, creeks, and rivulets. So the geographical condition and position also inspired the Bara-Bhuiyans for the struggle of their independence. "So it is very natural that during these years of unrest 
and instability, taking advantage of the absence of a strong central government, the bhuiyans became independent in their respective territories."

Abdul Karim also solves some historical points made by C.W.B. Rouse and N. K. Bhattasali. Rouse didn't his information about the rise of Bara Bhuiyans; to him, in the time of exchanging the power between Afghans and Mughals chiefs or Bhuiyans practically emerged in Bengal. But he didn't point out anything on the rise of Bara-Bhuiyans. To the other hand, Bhattasali commented the rise of Bara-Bhuiyans dated with the fall of Daud Khan Karrani in 1576. Here Abdul Karim proved that while writing this, Bhattasali did not note that even before Daud's fall Isa Khan had gathered enough power to defeat Shah Bardi's Mughal navy. He also thought the Bara-Bhuiyans arose all over Bengal, but we saw above that the Bara-Bhuiyans rose to power in Bhati.

\section{Significance of the name of Bara-Bhuiyans and their identity}

Historians have different views on the naming and numbering of the Bara- Bhuiyans of Bengal. Abdul Karim analyzed the formulas obtained by combining all the opinions and was rather successful in determining the significance and number of their naming. Many prominent researchers of Bengal have incorporated the concept of Bar Bhuiyan, which is prevalent in Bangladesh, in imitation of East Indian Assam, Kochbihar, Shyamdesh, and Arakan. And they used to mean many bhuiyans by the term "Bara-Bhuiyans". In consequence of the fact, Satish Chandra Mitra and M. A. Rahim were not certain about the areas and numbers of Bara-Bhuiyans; they commented that no reason to determine it that Bara-Bhuiyans are the specific twelve numbers of bhuiyans, rather the term meant the number of bhuiyans those established control over many territories in Bengal. Likewise, European researchers perceived that all landlords of Bengal were largely included as Bara-Bhuiyans.

Bhattasali viewed, the Bara-Bhuiyans of Bengal received the appellation on the analogy of Assam. He said that from the history of Assam, noted that several small Chiefs emerged and became independent when the overland disappeared or became weak. The common name was Bara-Bhuiyan. When conditions in Bengal became similar in 1576, with the fall of Daud Khan Karrani, the repression of the BaraBhuiyans of Assam by Bisva-Simha was still new in everybody's mind. Thus, on Assam's analogy, the independent chiefs who emerged in Bengal promptly earned the name of Bara-Bhuiyans. The most logical interpretation of the nomenclature seems to Bhattasali to be that. He also affirmed sided with the almost same opinion of S. Mitra $\left[{ }^{25}\right]$. So, Bhattasali and all previous researchers explained 'Bara-Bhuiyans' with the rigid view that they took their jurisdiction over all Bengal. But the contemporary historians of the time like Mirza
Nathan, Abul Fazal when cited Bara-Bhuiyans, they also mentioned Bhati. Even they confined the BaraBhuiyans within the area of Bhati. Of course, Bhattasali discussed that those Bhuiyans fought against Mughal to save independence and freedom, they should be recognized Bara-Bhuiyans only; although he stated it from another standpoint. Jadunath Sarkar also viewed that Bara-Bhuiyans spread all over the Bengal region. Here Abdul Karim clearly uttered that the historic BaraBhuiyans were the Bara-Bhuiyans of Bhati only, not the bhuiyans of whole Bengal. And he affirmed these BaraBhuiyans rose against the Mughal aggression during king Akbar and Jahangir for the sake of the freedom of their motherland.

Appreciating all discussions on actual numbers of Bara-Bhuiyans, Abdul Karim gave the priority and believed as a more reliable source than all others the Baharisn-i-Gaibi of Mirza Nathan. He came to the decision that Bara-Bhuiyans were exact twelve in number, Abul Fazal as well as Mirza Nathan mentioning also the number as twelve; but in their books, in the reign of Akbar and Jahangir, they enlisted and mentioned total thirteen names of Bhuiyans. Abul Fazal for example said that Isa Khan gained fame and made himself subject to the 12 zamindars of Bengal. Likewise, Mirza Nathan used to state that Musa Khan and twelve of his allied zamindars. Abdul Karim explained the fact, according to Abul Fazal, the actual number of bhuiyans was twelve, with the chief or leader Isa Khan during Akbar's period they were total thirteen. Similarly, Mirza Nathan identified Musa Khan during Jahangir with his allied twelve zamindars of Bhati, thus they were also thirteen. Moreover, it is also verified, Musa Khan was subjected to all Bhuiyan by his military skills and diplomatic supremacy, inheritably after Musa Khan, Isa Khan became the leader and chief of BaraBhuiyans.

So, according to the documents of Mirza Nathan and Abul Fazal, Abdul Karim listed the BaraBhuiyans during Akbar as follows:

01. Isa Khan Masnad-i-Ala (chief of the BaraBhuiyans)

02. Ibrahim Naral (Sunargoan pargana )

03. Karimdad Musazai (Maheswardi pargana)

04. Majlis Dilawar (Joanshahi)

05. Majlish Pratap (Khaliajuri)

06. Tila Ghazi (Bhawal region)

07. Kadar Rai (Bikrampur)

08. Sher Khan (

09. Bahadur Ghazi (Bhawal)

10. Chand Ghazi (Chandpratap pargana)

11. Sultan Ghazi (Sultanpratap pargana)

12. Selim Ghazi (Selimpratap pargana)

13. Qasim Ghazi (Qasimpur and Talibabad)

During Emperor Jahangir, the Bara-Bhuiyans with their leader Masnad-i-Ala Musa Khan have been 
mentioned following the description of Mirza Nathan as follows:

01. Musa Khan (The head of the Bara-Bhuiyans, the son of Isa Khan)

02. Alaul Khan (Nephew of Isa Khan)

03. Abdullah Khan (son of Isa Khan)

04. Mahmud Khan (son of Isa Khan)

05. Bahadur Ghazi (Bhawal pargana)

06. Suna Ghazi (Bhawal)

07. Anwar Ghazi (Bhawal)

08. Shaikh Pir (alley of Musa Khan)

09. Mirza Mumin

10. Madhav Rai (Khalsi parfana, Manikgunj)

11. Binode Rai (Chandpratap pargana))

12. Pahiwan (Matanga pargana)

13. Haji Shams-ud-Din Baghdadi (alley of Musa Khan)

We saw that there were twelve Bara-Bhuiyans, both Abul Fazal and Mirza Nathan mentioned the number as twelve. So we have to look for them in the Bhati region to classify the Bara-Bhuiyans. Abul Fazal stated Isa Khan was the zamindar of Bhati and 12 zamindars of Bengal subjected to him. On the contrary, Mirza Nathan exposed that Islam Khan would personally go to Bhati after the rainy season, to punish Musa Khan and the region's zamindars.

Now, question is to arise, Bara-Bhuiyans those were specific numbers twelve and thirteen along with their chief, what was the region they subjugated and took arms against Mughals? The previous researchers traced them throughout the whole Bengal region and looked them all over Bengal territories; the same thought of the scholars was mentioned above. But Abdul Karim finally decided that Bara-Bhuiyans or Twelve zamindars ruled over only Bhati of Bengal or a definite geographical area of East Bengal, none them for the whole Bengal. He assessed all existing documents and pointed out a comparative analysis of the materials regarded in the region of Bara-Bhuiyans.

Contemporary and modern European scholars took effort outlining the boundary of Bara-Bhuians and a brief history of their struggle indicating with the individual region. Portuguese Du-Jaric and Bishop Dom Padro discussed Bengal from letters and reports of their people who visited Bengal, though they never visited the region. Thus, their writings cannot be much relied upon. But Fray Sebestien Manrique visited Bengal and passed a time in the region with India, who failed to identify the boundary line of Bara-Bhuiyans, where he cited twelve kingdoms of Bhuiyans throughout Bengal territory. On the other hand, English traveler Ralph Fitch made valuable information about Bara-Bhuiyans and their region of Bhati. He said all of the Bhuiyans were involved in rebels against Akbar, since, there are numerous rivers as well as islands here that they can fled from one side to another, and the horsemen of Akbar were unable to triumph against them. So it can be decided from the descriptions of Ralph Fitch that the area of Bara-Bhuiyans located the riverine Eastern Bengal, not the whole Bengal. As a result, the Mughal expansion was marked as incomplete without uniting the eastern part of Bengal and they had indeed a precarious whole over the region. Hence, some parts of Bengal remained under the control of Mughal during Akbar.

Though river oriented East Bengal (Modern Bangladesh) with its Bhati region (particularly Sherpur district, Demra of Dhaka, Savor of Dhaka, Ghatail of Tangail district, Norsingdi district) were captured By the Mughal force for a very short time, East Bengal with Bhati would be re-occupied by independent landlords. And analyzing all existing sources and references, Abdul Kaim was the scholar who sketched out the Bhati kingdom of Bara-Bhuiyans accordingly as:

---The above discussion helps us to determine the limits of Bhati as follows: The river Ichamati in the west, the River Ganges in the south, the kingdom of Tipper in the east and to the north Alapsingh paragana in the greater district of Mymensingh stretching towards north-east to Baniachang in Sylhet. The low-lying area of greater districts of Dhaka, Mymensingh, Tippera and Sylhet; watered and surrounded by the three great rivers the Ganges, the Brahmaputra and the Meghna and their numerous branches constituted Bhati in the days of Akbar and Jahangir. (Karim, History of Bengal, 1992, p. 113).

\section{The resistance of Bara-Bhuiyans against Mughal aggression and the assessment of their defeat \\ It was already mentioned, the Bara-Bhuiyans} aroused in Bengal led by Musa Khan and Isa Khan immediately after the fall of the central political power of Bengal, with the downfall of the last king of the Karrani dynasty - Subedar Khan Jahan (1575-1578) led the Mughal army where Daud Khan Karrani was defeated. In this transition of political power, Isa Khan was the greatest amongst Bhuiyans (Landlords) of Bengal in the time of Mughal aggression. According to Akbarnama, even Mughal naval commander Shah Bardi fell into the assaulting of Isa Khan in the time of Subedar Khan Jahan. Abdul Karim assessed the fact that when Khan Jahan went back from East Bengal without any decisive result against Bara-Bhuiyans in 1978, Tila Ghazi of Talibabad got intrigued by Mughal and Ibrahim Naral surrendered to Subedar. If this two Bhuiyans would have not stung Isa Khan, Mughal would have ruined adversely. Such internal conspiracy, rebels, surrendering, secret collisions were a normal phenomenon in the contemporary Bengal. The amazing fact is that he had never submitted loyalty to Mughal until his death. After Isa Khan, though they were forced to surrender, his son Musa Khan with all other successors made watch vigilance and built a strong wall of resistance against the Mughal Empire. 
Isa Khan's first march noted stopping Mughal's extension in $1578 \mathrm{AC}$; temporarily he was defeated by Mughal in the confrontation, then reinforced with the aid of Tripura's king Amar Manikya and retreated Mughal's army. Consequently, he was able to establish his jurisdiction over almost Eastern Bengal after a series of military operations against Mughal and local landlords and resulted in the title being taken himself "Masnad-i-Ala." And the successive mutiny of Bengal's Mughal army commanders induced Isa Khan to consolidate his supremacy over the region of East Bengal. Abdul Karim assumed that Isa Khan succeeded in position as the leader of Bara-Bhuiyans within the year from 1580 to 1584 , then took the scope of the restless political turmoil in the cause of Mughal commanders' rebels in Bengal, he expanded his power and entitled himself Masnad-i-Ala.

Then Muzaffar Khan (1579-1580) was appointed as Subadar of Bengal, though he failed to suppress rivals of Bhuiyans. As a ruler, yet clearly his intellectual powers had now weakened and he had lost his former vision clearness, and rapid decision on power. After just one year, the tragic tale of his viceroyalty ended in his assassination at the hands of his mutinous soldiers. Meanwhile, the rebel's power of Mughal formed a government in Bengal in the name of Akbar's brother Mirza Hakim, and finally, Akbar succeeded in recovering the rival occupied lost territories in 1581. Mughal ruler Khan Azam Mirza Aziz Koka (1582-1583) came to power, but he was reluctant to invade Bara-Bhuiyans. Next, Shahbaz Khan (1583-1586) came forwarded to control Bara-Bhuiyans in 1584 against Isa khan and Masum Khan kabuli as well soon after getting his post as a Subadar. But he completely failed to subjugate Bhati. Masum Khan Kabuli or Isa Khan, none could be dislodged from their powers and the rule of Mughal was restricted to its former locations in Ghraghat in the north and Sherpur Murcha in district Bogra. In the middle of two times of Shahbaz Khan, Sadik Khan served as subahdar in 1885 and he was failed to be a success in occupying Bhati. After him, Shahbaz Khan again afforded invasions two times more since all appeared failures. On the contrary, Isa Khan founded his authority whole region from Sonargaon to Agarasendhur, Sarail within 1584. According to Ain-i-Akbari and Jadunath Sarkar, Shahbaz Khan took a phase of solidarity and peace in Bengal in his last chapter of the ruling session. Where Abdul Karim asserted, Shahbaz Khan was not able to achieve anything in Bengal and he didn't establish control over the Bhati region. Then Wazir Khan came to power for one year (1586-1587), and he passed away without any triumph. Furthermore, during Said Khan (1588-1594), no descriptive fleet appeared in history for six years of his reign.

Subahdar Raja Man Singh Kachwah (15941605) founded the city Rajmahal in 1995 and transferred the capital of Bengal from Tanda. On the same year, Man Singh advanced towards Bhati against Isa Khan and Masum Khan Kabuli, because both attacked Ghoraghat. Yet they had to withdraw due to the lower water flow of the river, and went back to the Kinara Sindur (Egara Sindur) on the river Brahmaputra. But Man Singh again possessed a vast fleet to Bhati in 1597 that was a failed campaign. Isa Khan and Masum Khan prudently faced the attacks from their strategic position, and in the battle of Bhati against BaraBhuiyans the son of man Singh Durjan Singh was killed who invaded Katrab (the capital city of Isa Khan) and Mughals were defeated adversely, unfortunately, Man Singh returned from Bengal without any achievements against Bara-Bhuiyans.

The year 1599 carried great mishaps for the history of the Bara-Bhoiyans and all at once a matter of good luck of Mughals, because demises of Masum Khan Kabuli and Isa Khan were happened in natural. Giving information about the death of Isa Khan, delighted Abul Fazl writes "By wondrous fate that turbulent landholder died and the thorn bush of commotion was extirpated." But after the death of Isa Khan, Man Singh failed to send any more expeditions against Bara-Bhuiyans of Bhati except the suppression of the member of Bara-Bhuiyans Kedar Rai of Bikrampur and Sripur. Man Singh himself led the expedition against Bhati in 1603 and 1604, and he conquered the whole region according to Abul Fazal and founded Thanas at strategic locations. But it is hard to say how far the testimony of Abul Fazal will be believed. Since events later show that as before, Bhati remained outside of Mughal's control. The entire Bhati is found in the possession of Bara-Bhuiyans when Islam Khan Chisti took over as subahdar. The Mughals had only one thana at Alapsingh pargana, also captured by Khwaja Usman on the eve of Islam Khan's appointment of a provincial governor of Bengal.

After Akbar, Emperor Jahangir came to the throne, two subahdar Raja Man Singh (1605-1605) and Khan Azam Mirza Aziz Koka (1606-1607) respectively took the governorship of Bengal. And their tenure was followed with uneventful consequences in the Bhati as well as Bengal. Then subahdar Islam Khan Chisti (1608-), the most familiar and premeditated skilled warrior, led the Mughals army and gained against BaraBhuiyans by which the three-era resistance struggle of glorious Bara-Bhuiyans came to an end. Hence, he proved to be a very successful subahdar through which he gained such success that no other subahdar had attained.

According to Mirza Nathan and Abdul Latif's dairy $\left[{ }^{26}\right]$ provide the intuition that Islam Khan rightly realized that Bhati's Bara-Bhuiyans were the key impediment to Mughal power in Eastern Bengal. Till the reign of Akbar, Bengal was remained to conquer. After getting an appointment, Islam Khan rose to the occasion and gave proof of his skill by subjugating the 
whole of Bengal within a short period of four years and a half. Of course, the emperor promoted Islam Khan's rank in times and even regularly showered favors and necessary supports upon him in his turn by sending reinforcement of soldiers, advisors, equipment and arms, artillery and gun powder, and whatever required from subahdar. So, He drew up his action plans carefully and was able to conquer battle after battle, overcoming all challenges with fortitude and determination. In Baharistan, notable sides of his action plan were given like he decided to march to Bhati and Bara-Bhuiyans, he deployed dutiful loyal well-trained armed forces, arranged organized and strong navy marching towards Bhati, moved the capital from Rajmahal to Dhaka, as the focal point of Bhati, defeated and submitted zamindars were not allowed by him go back to their territories but enrolled into imperial services so that they played off each other among them.

\section{Expedition to Bhati and surrender of Bara- Bhuiyans:}

Coming out from Rajmahal to Ghoraghat (Dec. 1608 - Oct. 1609), Islam Khan won the submission of Birbhum, Pachet, and Hijli with other two big zamindars- Raja Prapaditya of Jessore and Bushana's Raja Satrajit. Subahdar also sent fleets for fighting against Suna bazu, Shazadpur (both were situated in modern Pabna district) and Chandrapratap pargana (in Manikganj district). He made north, west, and south Bengal free of enemies through diplomacy, persuasion, conflicts, and battles; the zamindars and chiefs there either submitted willingly or were compelled to submit. Therefore, Islam then Khan completed all preparations for the invasion to Bhati while being fully free from disobedient and rivals zamindars from all sides throughout the whole Bengal within $1609 \mathrm{AD}$ and set out from Ghoraghat after the rainy season. Immediate before the expedition to Bhati, the most important decision was taken by Islam Khann establishment of capital at Dhaka, and he sent warboats, artilleries, and imperial fleet to Dhaka where a fort was also made with declaring it as the new capital of Bengal. Musa Khan and his allies presumably did not oppose it because they were devoting all their attention to Islam Khan.

The first phase of the Mughal-Bara-Bhuiyan War took place before Islam Khan took three months to arrive at Dhaka. The imperialists now came face to face with the Bara-Bhuiyans, with Islam Khan at Katasgarh and the Imperial Navy at Khal Jogini. The impregnable Jatrapur $\left[{ }^{27}\right]$ fort of Musa Khan lay near Katasgarh. The Mughal force marched with keeping deep vigilance out of Katashgarh toward Jatrapur fort. On the way of forwarding Jatrapur, the Mughal army built strengthens security walls throughout all of their campaigns. Musa Khan and Bara-Bhuiyans now constructed Dackchara $\left[{ }^{28}\right]$ fort near Jatrapur frot with a deep trench on the bank of the Padma where the imperial army was halting. Isalm Khan also ordered to dig a canal for making direct navigation in touch with Musa Khan's forts. After three days' indecisive war between both sides, Islam Khan succeeded in marching very close to Jatrapur. Musa Khan realized to reach a truce with the Mughals and met with subahdar. But arising a misunderstanding among both on misbehave of a dancing girl of Islam Khan, Musa Khan then seriously considered for fighting against Mughal. Meanwhile, the most amicable ally of Musa Khan Majlish Qutub of Fathabad (previous Faridpur) was defeated by Mughal force and Khawja Osman was fully encompassed by the Mughal army with strict surveillance; Bara-Bhuiyans and Musa Khan fought with mighty Mughal power since three months. At final, Musa Khan and BaraBhuiyans were defeated and retreated to the river Lakhya and making the river as his base of defense he began preparation for the second and final phase of the war with Mughals. On the contrary, occupying Dakchara and Jatrapur fort, the happy heart Islam Khan started for Dhaka intended for overthrowing the rest of the Bhati area.

With reaching Dhaka Islam Khan deployed a well-equipped Mughal army to all strategic positions and posted loyal admirals based on a topographical assessment to defeat Bara-Bhuiyans of East Bengal. Musa Khan was also ready for battle; he stressed the defense of the Lakhya river, where Katrabo, his headquarters his capital city, and Sunargaon, were laid on. Hence, he defended the Bandar canal; this canal flows through Sunargaon and meets the river Lakhya, where it is known as Tribeni Khal; he constructed two forts on two sides of the canal of Bandar, and he took his position in one fort. But, surprisingly, Musa Khan did not take action to protect Khizirpur, which on one side controlled the Lakhya River and on the other the Bandar canal. He left Khizirpur to be occupied by the imperialists; he had not realized that Islam Khan would win half the battle by occupying Khizirpur. Islam Khan sat a mosque in Khizirpur and held a council of war. It was decided there that Itimam Khan should take command of Khizirpur, and that Shah Rukn should march to Demra Khal (Demra canal) against Mahmud Khan, Mirza Nathan would go to Katrabo in opposition to Daud Khan, and Shaikh Abdul Wahid would campaign for Chaura aligned with Bahadur Ghazi. Islam Khan reiterated his preceding order to name some loyal admiral at different locations in Bhati. The imperialists, having made all these precautions, launched an assault on 12 March 1611.

After taking place a great battle and a hand to hand fight, the fort of Katrabo was occupied by Mirza Nathan and the imperial fleet; similarly, the place Qadam Rasul and the procession of Bandar khal were also won by Mughals. All of a sudden, Mirza Nathan and other admirals fell upon Musa Khan's fort, and upon the arrival of the elephants near the fort, Musa Khan left the fort without a battle to save himself and 
fled. Also, Mirza Mumin followed his leader Musa Khan for captivating protection.

But in the meantime, the Bandar was filled with the river's flow-tide, and crossing back for men and horses became difficult. When zamindars saw the Mughals' pitiful state, they dropped onto the troops who had already crossed the other side. And again there was a great war going on, but at last Musa khan and his allies retreated to Sunargaon. Sunargaon then was occupied ruled by imperialists and Musa Khan fled to the island Ibrahimpur $\left[{ }^{29}\right]$. Musa Khan, after this war, lost his fighting capacity against the Mughal army. Islam Khan realized there was no longer any need to send expeditions against him. After the subjugation Bhati, Islam Khan now received the submission of Bahadur Ghazi (Chaura) and Majlish Qutb (Fathabad). $\mathrm{He}$ also sent expeditions against an ally of Musa Khan Ananta Manikya of Bhulua (modern Noakhali district), and Bhulua was conquered just before the rainy season in 1611. After the fall of Bhulua, in his struggles, Musa Khan lost all hope and saw no other way to protect him than to surrender to Islam Khan. Thus, finally with the mediation of imperial officials, Musa Khan along with all his brothers and allies submitted to Islam Khan; they were kept under the supervision of Mughals and for their upkeep, each estate of them was given back as their jagirs.

When Musa Khan and his zamindar allies submitted to Islam Khan, Anwar khan of Baniachang and Pahlwan of Matang were within their respective territories. They put up a strong fight at fort Dakchara with Musa Khan but returned to their respective places after the first phase of the battle. Islam Khan sent expeditions against Anwar Kahn and then his brother Husain Khan and they attempted to fall Islam Khan and the imperialists with several strategies. But after some severe battles, they had no choice but to surrender to the Mughals themselves. Similarly, Pahlwan of Matang's decline and fall hiked a serious battle against the enemy but lost. So Matang, Bara-Bhuiyans' last stronghold, was caught.

\section{CONCLUSION}

N K Bhattasali once expressed with grief:

--- It is very greatly to be regretted that the importance of Isa Khan's struggles has not even now been seen in its proper perspective, - no scholar has yet turned up even to look up the references given by Mr. Beveridge or to read through the whole of Akbarnama and other cognate works to find out if further details of Isa Khan's struggles are available. (Bhattasali, 1928, p. 39). Happily, we can remark that historian Abdul Karim has fulfilled the expectation of previous scholars and bought Bara-Bhuiyans and their glorious history in the daylight.
With the capture of East Bengal of BaraBhuiyans, Islam Khan put an end to the rival power in the whole of Bengal and easily won all other obstacles. He drew up his action plan vigilantly and carried out it with bravery and commitment, and overcame all challenges with intensity and determination. Islam Khan had no alternative to the conquest of Bhati and to be the provincial governor of Bengal for breaking the strong resistance of Bara-Bhuiyans like lead cast wall against an imperialist power. Mughal had no dearth of war equipment that was needed to put over BaraBhuiyans and their region Bhati. On the other hand, Bara-Bhuiyans had no elephants and large cavalry except in the navy, but above all for their motherland, they had indomitable bravery and patriotism and love of independence. "It should also be noted that this was an unequal war on the one side, there was the subahdar of Bengal with the active support of the great Mughal emperor and on the other hand, there were a few zamindars of a part of a subah."

The main missile of the Bhuiyans was their morale against the large imperialist forces equipped with modern weapons. Since some pragmatic strategies can also be traced for the loss of freedom from the side of Bara-Bhuiyans.

It has been stated that by leaving Khizirpur undefended Musa Khan committed a big mistake. He should have realized that Khizirpur is more important than protecting both the Bengalese army and Islam Khan. Musa Khan was supposed to have occupied and strengthened Khizirpur, because it maintained the connectivity, on one hand, Katrabo and Chaura and, on the other side, Sunargaon and the Bandar Canal was maintained by it. Musa Khan permitted them to capture both the wings of his army and naval facilities in a position of command and advantage, by enabling the Mughals to capture Khizirpur. (Karim, History of Bengal, 1992, p. 260)

War strategic policy from both sides and their plan of action also contributed to obtaining defeat and victory. Reviewed and observed from both sides' policies that Musa Khan's approach seems to have been defensive while Islam Khan has taken offensive measures. Abdul Karim truly appreciated that both Musa Khan and Islam Khan were racing to capture strategically important positions, as Musa Khan took defensive action and Islam Khan was also taking offensive preparation; and Islam Khan was able to occupy Khizirpur first in the battle.

Mughal army was well-equipped and reinforced with all requirements in the Bhati campaign against Bara-Bhuiyans, imperialist were superior in expeditions where zamindars were inferior in numbers and artilleries except gallant resistance. Despite the higher positions, Mughal soldiers who were killed in the battle, their families were given a big amount of 
financial supports; and on the eve of commencing battle, all soldiers were given golden coins and a huge amount of money as an incentive for fighting. Thus, by a blessing with financial inducement, the Mughal army did not hesitate to fight Bara-Bhuiyans and they were not going back to fight to the death. On the contrary, Bara-Bhuiyans and their soldiers were encouraged and motivated by grabbing the spirit of patriotism only. Hence, if the Bara-Bhuiyans did not have patriotism and indomitable courage, they would have colluded with the Mughals to gain their interests and maintain their zamindari without valiant resistance and fighting against the Mughal imperialism.

Abdul Karim is credited with who is the first pioneer of inscribing the magnificent history of freedom fighting of Bara-Bhuiyans against the Mughal Empire. Due to the scholarly contributions of Abdul Karim, the chapter of the historical struggle of Bara-Bhuiyans against Mughal aggression proved the fact that the epoch chapter of Bara-Bhuiyans was a struggle to survive, fight to protect the homeland, and strive to uphold the independence of their motherland Bhati region of East Bengal. We surely want that BaraBhuiyans and their independent war will be models to guide us in the path of heroism, of nobleness, of selfsacrifice and above all, of patriotism. The history of Bara-Bhuiyans does teach us to lead our lives being independent. Hence, Abdul Karim was successfully able to provide all evidence regarding the glorious era of the Bara-Bhuiyans, which magnificent episode of Bengal history leads us to achieve our independence in successive events against British colonial rule and even in the event of the emergence of Bangladesh.

\section{Endnotes:}

${ }^{1}$. Twelve famous independent landlords of the east region of Bengal.

2. Low-lying and riverine lower region of Bangladesh (in the Mughal period even in British colonial rule, modern Bangladesh was recognized as East Bengal or Eastern Bengal) that was comprised of the lower territories of the greater Dhaka, Mymensingh, and Sylhet districts.

3. The Mughal Empire was established in 1526 by Mongolian leader Babur when he defeated Ibrahim Lodi, the last of the Afghan Lodi Sultans, in the First Battle of Panipat, first used gunpowder in India. It was a Muslim dynasty of Turkish-Mongol origin that ruled Afghanistan, Baluchistan, and most of the Indian subcontinent from the early 16 th century to the mid- $18^{\text {th }}$ (1526-1761 AC). After that, it continued to exist until the mid-19th century as a considerably reduced and increasingly powerless entity. During Emperor Akbar the great (1556-1605), the Mughal empire grew considerably over Indian Subcontinent; that time, the emperor sent series of military campaigns for subjugation Bengal province. But the Mughal rule was remained to constant with only some parts of Bengal. During Akbar and a long time of Jahangir, the subahdar (rulers of Bengal province) and their forces could not capture the whole Bengal for a long time.

4. On the eve of the Mughal invasion to Bengal, independent or semi-independent landlords in Bengal at that time, they were called Bhuiyan.

5 . Bengal's last independent sultan was Daud Khan Karrani (1573-1576). When Hansu's treachery killed his elder brother Bayazid, Daud, with the aid of the faithful nobles of Sulaiman karrani, ascended Bengal's throne and continued his brother's independence policy. Unfortunately, he engaged in cold relations with Akbar due to his weak diplomacy. Finally, on 12 July 1576, a decisive battle was held at Rajmahal with Akbar's forces. The Independent Sultanate of Bengal ended up, and Daud was defeated and executed. (Available at http://en.banglapedia.org/index.php?title=Daud_Khan_ Karrani ).

${ }^{6}$ Sayyid Ghulam Husain Salim Zaidpuri wrote the book in Persian in 1788 at Maldah, which covers the whole period of Muslim Bengal, from the Muslim founder ruler Bakhtiar Khilji's campaign to the British rule in Bengal.

7. The book published from Cambridge University Press, Online publication date: February 2015, Available

https://www.cambridge.org/core/books/history-ofbengal/1545F48F9EA81F36415790AC62F084B7

8 . The book published from London in1791 A D. Available

http://cslrepository.nvli.in/bitstream/123456789/3962/2/ RB793.pdf

9. He also completed an important book as "Notes on the Races, Castes and Trades of Eastern Bengal" published from London in 1883, and the book is famous to all as Eastern Bengal. He was an indigo planter who discovered many Arabic and Persian inscriptions from Dhaka, Sonargaon, Dhamrai and the neighboring places and sent these and their facsimiles to the Asiatic Society of Bengal, Kolkata, where Henry Blochman published them in the society's journal. When the Director of Archaeology of British India, Sir Alexander Cunningham, visited Dhaka and neighboring places, James Wise helped him understand various historical sited regions, including Sonargaon and Bikrampur. (Abu Imam, Sir Alexander Cunningham and the Beginning of Indian Archaeology, Dhaka, 1966, p.123.) 10. "Contributions towards the History and Geography of Bengal," published in the Journal of the Asiatic Society of Bengal for 1873, and in his translation of the Ain-i-Akbari, Vol. I, p. 342, footnote, speaks of the twelve

Bhuiyans of Bengal. (N. K. Bhattasali, Bengal Chiefs' Struggle for Independence in the Reign of Akbar and Jahangir Bengal Past and Present, Calcutta, XXXV, 1928, p. 25. Retrieved from 
https://archive.org/stream/in.ernet.dli.2015.32675/2015. 32675.Bengal-Past-And-Present--Vol35_djvu.txt )

${ }^{11}$ The book comprised of Codes of Mughal emperor Akbar and Laws of the Mughal India, and the main Persian script written and compiled by Abul Fadl who was the court writer of Akbar.

12. Westland's Jessore published in 1871, and Beveridge's Bakarganj published in 1876; these two books are mention to connect the same subject of Bhuiyans. But the books are not seriously concerned with the history of any Bhuiyan of Bengal.

13. N. K. Bhattasali, Bengal Chiefs' Struggle for Independence in the Reign of Akbar and Jahangir Bengal Past and Present, Calcutta, XXXV, 1928, p. 26. Available at:

https://archive.org/stream/in.ernet.dli.2015.32675/2015. 32675.Bengal-Past-And-Present--Vol35_djvu.txt

14. These canons are now in the Dhaka National Museum, and on one canon, the name of Isa Khan with the date and title has been inscribed.

15. The book was published (Butterworth \& Co. Ltd. Was the publisher) from Calcutta in 1919. The writer relied on a collection of Portuguese sources in writing the book. This book has been grown out a series of lectures delivered on the commemoration of the fourth century of the advent of Portuguese in the Bay of Bengal at Union Chapel Hall in Calcutta under the auspices of the Indo-Portuguese Association and Yung Marr's Union on April 1918. The book available at: https://archive.org/details/in.ernet.dli.2015.233560/page /n11/mode/2up.

${ }^{16}$. N. K. Bhattasali stated that these articles of Kailash Singa printed in the J.A.S.B. of 1874 and 1875. Still, he didn't see these articles of Kailash Sinha..

17. B. S. does mean Bengali Sambat or the Bengali calendar is called Bengali Sambat (BS) or the Bengali year (somewhere in Bangla Sôn (evsjv mb/evsjv mvj)somewhere in Bangla sal or Bangabda) has a zero year beginning at 593/594 CE. ... The traditional Bengali calendar continues to be in use among the Bengali community in Bangladesh and India.

18. Based on Sylhet's local tradition and some contemporary sanads he had discovered in some Muslim Zamindar family of Sylhet, he wrote an article about Osman in the "Protibha" magazine of Calcutta in1320 B.S.

\footnotetext{
${ }^{19}$ Prof. Satish Chandra Mitra wrote: "History of Jessore and Khulna, Part II" (pub. 1329 B.S.). The book deals with Pratapaditya in-depth, and all the Bhuiyans in more brief. This is a memorial to the patient industry and the author has been able to collect many valuable pieces of knowledge and topographical data from local investigations. Yet historical perspective is lost in the elaborate attempt.

Available at

https://archive.org/details/in.ernet.dli.2015.289453/page /n1/mode/2up.
}

20. M. A. Rahim asserted the relevant discussion of Bara-Bhuiyans in his book The History of Afghans in India, Karachi, 1961.

21 . Last Independent dynasty (founded by Taj Khan Karrani 1563 and lasted till 1576 with the fall of Daud Khan Karrani by Mughal forces) in Bengal before Mughals. In many respects, the short rule of the Karranis is significant in Bengal's history. This marked the end of Bengal's independence and the start of the Mughal rule.

22. He was the founder of the Sur dynasty of Delhi (1540 to 1556$)$ and the emperor of north-east India (1540-1545). In his early career, he got a job under Bahar Khan Lohani, Sultan of Bihar Upon Bahar Khan's death, Sher Khan became Bihar's virtual ruler as the regent of the sultan's minor son Jalal Khan. Jalal Khan became jealous of Sher Khan, seeking the aid of the Bengal sultan Ghiyas-ud-Din Mahmud shah to free from Sher Khan's tutelage. Under Ibrahim Khan Mahmud sent an army to assault Bihar on Jalal Khan's behalf. Yet at the Battle of Surajgarh (1534), Sher Khan defeated the joint armies of the Bengal sultan and Jalal Khan. Being the ruler Bihar, in 1538 he invaded Bengal and defeated Sultan Mahmud Shah. (Banglapedia)

Available at

http://en.banglapedia.org/index.php?title=Sher_Shah

23 . He reigned 5 years $(1533-1538)$ and he was the last sultan or ruler of the Hussain Shahi dynasty (14941538) of independent Bengal.

24. Abdul Karim, Banglar Itihas (Sultani Amal), [History of Bengal (Sultanate Period)], $2^{\text {nd }}$ edition, 1987, p.101.

25. ---"I think Satish Babu is right in his second contention that number twelve is made to denote an indefinite number. It became a custom to speak of 'Twelve' Bhuiyans, whenever one had to refer to them, because their number was indefinite. The contemporary Western writers refer to them as 'Twelve' and even Abul Fazl calls them 'Twelve.' (Akbarnama, Beveridge's translation, Vol. Ill, p. 648.) They are also traditionally known as twelve in Bengal".

${ }^{26}$. The diary of Abdul Latif, discovered by Sir Jadunath Sarkar, is a very important source of Bara-Bhuiyans' knowledge, particularly for a year. The dairy is rather short and begins with the departure of Islam Khn from Rajmahal for Ghorarghat and ends with Islam Khan's departure for Bhati from Ghoraghat. Abdul Latif was Abul Hasan's favorite retainer who was Bengal's diwan (Chief Revenue Administrator from 1608 to 1612 AD). No excuse for not continuing his dairy where he served his master until 1612 AD was created. Sir Jadunath translated the diary into English as well as Bengali, but he left out a section that he felt was not significant to history. The dairy furnishes us with several dates that are very useful in reconstructing the chronology of different events in Bengal from the early years of Jahangir's reign. The dairy also gives valuable details about Bengal chiefs and zamindars visiting Islam Khan and offering submission with presents to the subahdar. 
27. Jatrapur is located about thirty miles west of Dhaka and a road from this place goes to Dhaka via Nawabganj.

28. Dakchara was about three miles north-west of Jatrapur and was located on the Ichamati river bank. The river Padma was to a little south of Dackchara and the colonial camp at Katasgarh was to a little west.

29. Ibrahimpur is recognized under Nabinagar of present Brahmanbaria district, and three and quarter miles south of Nabinagar police station; and also five miles far island from the eastern bank of the Meghna. It is also 28 miles north-east of Sunargaon.

\section{REFERENCE}

1. Bhattasali, N. K. (1928). Bengal Chiefs' Struggle for Independence in The Reign of Akbar and Jahangir. Bengal: Past and Present, 35(Part-1), 2539.

2. Fazl, A. (1897). Akbarnama (Vol. Vol. 3). (H. Beveridge, Trans.) Calcutta, Bengal, India: Calcutta Asiatic Society of Bengal.

3. Karim, A. (2005). Banglar Itihash, Mughal Amal (History of Bengal, Mughal Period) (2nd ed., Vol. vol. 1). Dhaka, Bangladesh: Jatiya Granthe Prokashon.
4. Karim, A. (1992). History of Bengal Mughal Period (Vol. 1). Rajshahi, Rajshahi, Bangladesh: Institute of Bangladesh Studies (IBS).

5. Nathan, M. (1936). Baharistan-i-Ghaibi (Vol. 2). (M. I. Borah, Trans.) Assam, Assam, India: Government of Assam.

6. Sarkar, S. J. (1948). History of Bengal (First Edition ed., Vol. 2). (S. J. Sarkar, Ed.) Dhaka, Dhaka, Bangladesh: University of Dhaka. 